Jurnal Konstruksi Hukum | ISSN: 2746-5055

Vol. 2, No. 1, Januari 2021 Hal. 144-148 | Tersedia online di https://www.ejournal.warmadewa.ac.id/index.php/jukonhum DOI: https://10.22225/jkh.2.1.2984.144-148

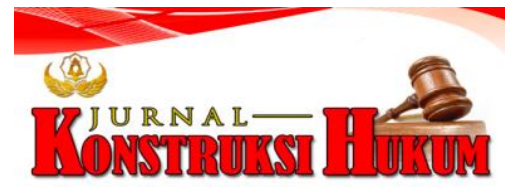

\title{
PELAKSANAAN PERUBAHAN HAK GUNA BANGUNAN YANG DIBEBANI HAK TANGGUNGAN MENJADI HAK MILIK UNTUK RUMAH TINGGAL
}

\author{
Komang Adhi Kresna Purnama, Nyoman Alit Puspadma, Ni Gusti Ketut Sri Astiti \\ Fakultas Hukum Universitas Warmadewa, Denpasar-Bali, Indonesia
}

\begin{abstract}
Abstrak
Penelitian ini bertujuan untuk menganalisis pelaksanaan perubahan hak guna bangunan yang dibebani hak tanggungan menjadi hak milik untuk rumah tangga dan menjelaskan perlindungan hukum terhadap kreditur yang objek Jaminannya telah dibebani Hak Tanggungan dimohonkan perubahan dari Hak Guna Bangunan menjadi Hak Milik. Metode penelitian yang digunakan dalam penelitian ini adalah penelitian hukum normatif dengan pendekatan perundang-undangan (statute approach) dan Pendekatan kasus (case approach). Sumber data adalah bahan hukum primer dan sekunder yang dianalisis secara kualitatif pengolahan data dilakukan dengan menguraikan dan menggambarkan seluruh bahan hukum sebagai hasil daris tudi dokumen dan wawancara yang disempurnakan dengan studi kepustakaan dan studi ketentuan-ketentuan yang berlaku. Hasil penelitian ini menunjukkan bahwa Pelaksanaan Perubahan Hak Guna Bangunan menjadi Hak Milik di Kantor Pertanahan diproses sesuai dengan ketentuan Peraturan Menteri Negara Agraria/Kepala Badan Pertanahan Nasional Nomor 5 Tahun 1998 tentang Perubahan Hak Guna Bangunan atau Hak Pakai Atas Tanah Untuk Rumah Tinggal yang dibebani Hak Tanggungan menjadi Hak Milik. Perubahan tersebut dapat dilakukan atas permohonan pemegang hak dengan persetujuan secara tertulis dari pemegang Hak Tanggungan disertai Sertifikat Hak Tanggungan pada Kantor Pertanahan dimana objek Hak Tanggungan itu berada dan untuk Pelaksanaan Perubahan Hak Guna Bangunan yang masih dibebani Hak Tanggungan menjadi Hak Milik mempunyai akibat hukum bahwa Hak Tanggungan yang bersangkutan menjadi terhapus (gugur) sebagaimana tercantum dalam ketentuan pasal 18 ayat (1) huruf d UUHT akan tetapi tidak menyebabkan hapusnya utang yang dijamin
\end{abstract}

Kata Kunci: Hak Guna Bangunan; Hak Tanggungan; Hak

\begin{abstract}
This study aims to analyze the implementation of changes in building use rights that are encumbered with mortgages to property rights for households and to explain legal protection for creditors whose objects of collateral have been encumbered with Mortgage Rights are requested to change from Building Use Rights to Property Rights. The research method used in this research is normative legal research with a statute approach and a case approach. Data sources are primary and secondary legal materials which are analyzed qualitatively. Data processing is carried out by describing and describing all legal materials as a result of document studies and interviews enhanced by literature study and study of applicable provisions. The results of this study indicate that the implementation of changes in building use rights to property rights in the Land Office is processed in accordance with the provisions of the Regulation of the State Minister for Agrarian Affairs / Head of the National Land Agency Number 5 of 1998 concerning Changes in Building Use Rights or Right to Use Land for Residential Land with Mortgage Rights become Property Rights. These changes can be made at the request of the right holder with written approval from the holder of the Mortgage along with a Certificate of Mortgage at the Land Office where the object of the Mortgage is located and for the implementation of changes in building use rights that are still burdened with the Mortgage Right to Ownership Rights have legal consequences that the Mortgage Rights the person concerned becomes erased (void) as stated in the provisions of article 18 paragraph (1) letter $d$ of the UUHT but does not cause the guaranteed debt to be written off.
\end{abstract}

Keywords: Building Use Rights; Mortgage right; Right

\section{PENDAHULUAN}

Tanah memiliki peran penting dalam kehidupan manusia seperti menjadi lahan untuk pembangunan perumahan, dijadikan lahan untuk membuat bangunan untuk perusahaaan. Rumah mempunyai guna sebagai tempat tinggal individu untuk menghindari dan melindungi diri dari iklim, rumah tidak bisa dimiliki secara langsung karena untuk menciptakan suasana rumah harus melewati prosesnya 
sesuai prosedur yang ada. Rumah memiliki dampak yang penting yakni untuk memenuhi kebutuhan masyarakat atau individu seluruhnya (JW, 2009).

Tanah merupakan modal utama dalam pembangunan bidang ekonomi fungsi tanah dapat menjadi sebagai modal usaha selain dilihat dari fungsi utama tanah saat ini tidak saja digunakan sebagai tempat tinggal namun sebagai tempat berlindung. Pemilik rumah, dalam memperlancar usaha atau kegiatannya tidak jarang pemilik rumah mengajukan kredit kepada Bank untuk memperoleh dana yang dijadikan sebagai modal hak tanggungan yang objeknya berupa tanah yang di berikan keterangan oleh pemilik tempat tinggal HGB dan hak pakai bisa digunakan sebagai penjamin utang yang disertai oleh Hak Tanggungan dijelaskan pada peraturan pemerintah yang mnengatur tentang status pertanahan berdasarkan ketentuan Pasal 4 UUHT Hak Guna Bangunan merupakan objek Hak Tanggungan (Usman, 1999).

Undang-Undang Hak Tanggungan berlaku di seluruh Indonesia termasuk di Kabupaten Badung. Status kepemilikan rumah tinggal memiliki keterangan sebagai HGB karena kegiatan membangun tempat tinggal digarap oleh orang-orang yang diperlukan dalam pembanguan dengan berdasar badan hukum. Setelah pemilikan berpindah tangan dari pengembang kepada pemilik baru perseorangan yang berwarga negara Indonesia melalui jual beli atau sebagainya, maka pemilik baru tersebut ingin mengubah status dari HGB menjadi HM tetapi yang menjadi kendala adalah apabila sertifikat HGB telah menjadi jaminan utang dan telah dibebani HT dimana sertifikat hak guna bangunan tersebut dipegang oleh pihak Bank selaku kreditur (Asikin, 1997). Saat tanah yang berstatus menjadi jaminan dan memiliki hak tanggungan dan ingin dirubah status tanahnya dari HGB menjadi HM oleh pemiliknya sering menimbulkan masalah, perubahan status tersebut bisa terjadi apabila pemilik tanah mendapatkan persetujuan dari Bank untuk tindakan tersebut terkait pemberian izin oleh pihak Bank, hal ini diakibatkan karena kekhawatiran dari pihak Bank apabila debitur wanprestasi dan pelaksanaan perubahan tersebut mengakibatkan hilangnya HGB yang berarti hapus juga HT tersebut. Berdasarkan pada UUHT yang menjelaskan apabila status dari tanah yang menjadi jaminan utang hapus maka HT akan hapus juga (Urip, 2013).

Peneletian sebelumnya mengungkapkan bahwa Realisasi perubahan/peningkatan HGB menjadi HM yang membawa implikasi Perubahan objek Hak pada dokumen yuridis, seperti Akad Kredit, APHT, SKMHT dll, dalam praktek tidak semuanya diikuti dengan pembaruan dan atau perubahan dokumen yuridis (Rahman, 2010). Penyewa memiliki hak untuk mendapatkan fasilitas ruko dan memiliki kewajiban untuk membayar biaya sewa yang sudah disepakati, sedangkan hak dan kewajiban yang menyewakan ialah berhak mendapatkan pembayaran dari penyewa dan memiliki kewajiban untuk menyerahkan ruko tersebut untuk dipergunakan oleh penyewa. Jika dikemudian hari terjadi keteledoran antara salah satu pihak yang berjanji maka harus mengganti rugi dan bertanggung jawab atas wanprestasinya (Prodjodikoro, 2011). Menurut Sofiatun, (2017) Pelaksanaan perubahan Hak Guna Bangunan atas tanah untuk rumah tinggal menjadi Hak Milik yang dibebani Hak Tanggungan adalah perubahan dilakukan atas permohonan pemegang hak dengan persetujuan dari pemegang Hak Tanggungan, dengan pernyataan persetujuan tertulis disertai penyerahan sertipikat Hak Tanggungan yang bersangkutan.

Untuk menghilangkan kekhawatiran tersebut maka sangat diperlukan perlindungan hukum untuk kreditur terhadap barang jaminannya sudah diberikan tanggungan dan ingin dirubah menjadi milik pribadi debitur. Agar setiap masyarakat memiliki sertifikat hak guna bangunannya yang sedang dalam proses aggunan didapat dengan mudah melakukan peningkatan hak menjadi milik pribadi (Hermayulis, 2000). Bertolak dari hal ini, maka penelitian ini bertujuan untuk menganalisis pelaksanaan perubahan hak guna bangunan yang dibebani hak tanggungan menjadi hak milik untuk rumah tangga dan menjelaskan perlindungan hukum terhadap kreditur yang objek Jaminannya telah dibebani Hak Tanggungan dimohonkan perubahan dari hak guna bangunan menjadi hak milik

\section{METODE PENELITIAN}

Metode penelitian yang digunakan dalam penelitian ini adalah penelitian hukum normatif dengan pendekatan perundang-undangan (statute approach) dan pendekatan kasus (case approach). Sumber data adalah bahan bahan hukum primer dan sekunder yang dianalisis secara kualitatif, pengolahan data dilakukan dengan menguraikan dan menggambarkan seluruh bahan hukum sebagai hasil daris tudi dokumen dan wawancara yang disempurnakan dengan studi kepustakaan dan studi ketentuanketentuan yang berlaku. Pencarian informasi normative berpatokan pada peraturan pemerintah yang 
berfokus pada tanah sebagai objeknya dan analisis dalam informasi yang didapat secara konseptual berkaitan dengan masalah dalam penelitian ini. Adapun sumber hukum yang digunakan guna menyelesaikan fenomena dalam perumusan masalah melalui studi dokumen data yang dikumpulkan berupa sumber sumber hukum utama, sehingga hanya sebagai tambahan dalam sumber literatur bersifat relevan pada masalah yang sedang diteliti. Setelah data terkumpul, lalu dianalisis secara kualitatif pengolahan data dilakukan dengan menguraikan seluruh bahan hukum sebagai hasil dari studi dokumen yang disempurnakan dengan studi kepustakaan dan studi ketentuan-ketentuan yang berlaku (Sugiyono, 2005).

\section{HASIL P DAN PEMBAHASAN}

\section{Pelaksanaan Perubahan Hak Guna Bangunan yang Dibebani Hak Tanggungan Menjadi Hak Milik untuk Rumah Tinggal}

Legalitas kepemilikan tanah menjadi hal yang vital dan perlu untuk dibuktikan, adapun kasus yang sering terjadi adalah apabila kepemilikan tanah status tanahnya masih sebatas hak guna bangunan (HGB) Tentu saja pemegang hak atas tanah pasti ingin memiliki status kepemilikannya yang lebih kuat PERUBAHAN hak diatur dalam Pasal 1 PERMEN Agraria No 5/1998 sebagai berikut. Pemerintah menjelaskan jika sebuah tanah yang sudah memiliki status dan hak tertentu dan pemiliknya menginginkan perubahan apabila ingin dirubah maka harus memberikan objeknya kepadanya dengan status yang baru Penggantian hak akan diproses apabila pemilik hak mengajukan permohonan lembar kesepakatan serta sertifikat itu sendiri perjanian antara debitur dan kreditur menjadi salah satu sifat dari hak tanggungan tersebut yang didasarkan atas itikad baik.

Bentuk dari kesepakatan tersebut bisa berupa di bawah tangan ataupun otentik tergantung dari kesepakatan dari para pihak. Apabila dilihat dari bentuk perjanjian maka para pihak yang berkaitan dapat membuat kesepakatan diluar maupun dalam negeri asalkan utang piutang yang terjadi mempunyai nilai pembangunan di NKRI (Adrian, 2014). Tahapan dan prosedur agar terjadinya penggantian HGB yang dijadikan jaminan utang piutang masih menjadi rumah pribadi dengan keterangan hak milik Pada Kantor Pertanahan dibagi dalam dua tahap yaitu 1 Penggantian dari HGB menjadi rumah tinggal berstatus hak pribadi. Berdsarakan Pasal 80 PERMEN Agraria/Kepala Badan Pertanahan Nasional No 9/1999 permohonan Hak Milik atas tanah dilampirkan dengan beberapa dokumentasi sebagai berikut:

a. Kartu tanda pendunduk yang mengajukan permohonan

b. Sertifikat tanah yang berkaitan

c. Bukti bahwa memang benar tanah digunakan untuk tempat tinggal yaitu Foto copy keterangan memang benar bangunan tersebut dijadikan tempat tinggal dilihat dari IMBnya atau SK yang dikeluarkan oleh Kelurahan setempat bahwa memang benarbangunan tersebut dijadikan untuk rumah pribadl dibuat ole pihak berwenang;

d. Foto copy SPPT PBB tahun berjalan atau terakhir

e. Surat keterangan yang dibuat oleh pemohon tentang detail tanah tersebut

Sertifikat yang sudah dirubah lalu di berikan tangungjawab sebagai objek jaminan dalam utang piutang yang sudah menjamin bahwa pembayarannya akan dilunaskan dengan keterangan sebuah tanah dengan status HGB pelaksanaan harus melalui dua tahapansebagai berikut:

1. Tahap Pemberian HT

Surat keterangan milik hak tanggungan yang sudah diberikan dari debitur kepada penerima dimana dalam hal ini pemilik utang sebagai pemberi HT dan Kreditur Penerima hak tanggungan sebagai dasar pemberian hak tanggungan yang dilakukan di Kantor pihak yang berwenang dengan bukti dibuatnya akta pemberian hak tanggungan. Akta pemberian hak tanggungan sah apabila dibuat dilembar yang hak asli memiliki tanda tangan oleh kedua belah pihak dari pemberi dan penerima HT penerima hak adalah kreditur dan pemberi hak adalah debitur serta dua orang yang berstatus menjadi sebagai saksi atas terjadinya perjanjian tersebut serta tempat yang berwenang. Masing-masing membawa salinan akta asli tersebut yang dibuktikan adanya tanda tangan dari pihak berwenang dalam hal ini adalah Akta pemberian hak tanggungan beserta dokumen-dokumen yang dibutuhkan serta sertifikatnya yang asli yang sudah diberitahukan dan diinfokan kepada kepala kantor yang berwenang selambat-lambatnya satu minggu setelah terjadinya kesepakatan yang ditandai oleh kedua belah pihak menanda tangani akta pemberian 
hak tanggungan tersebut memberikan informasinya harus menggunakan surat pengantar dari kantor PPAT dimana akta tersebut dibuat dengan membuat salinan tersebut rangkap dua

2. Tahap Pendaftaran pada Kantor Pertanahan

Apabila dokumen-dokumen untuk pendaftaran sudah diterima dari kantor PPAT maka sudah terjadi pendaftaran HT yang diperintahkan oleh Kepala kanotr Pertanahan terhadap dokumen pada akta pemberian hak tanggungan, dalam prosesnya pembuatan sertifikat hak milik memakan waktu yang tidak sebentar terdapat beberapa langkah yang harus dilakukan demi mendapatkan hak milik dibutuhkan waktu sekitar satu minggu namun sebelumnya harus mendaftarkan berkas-berkas yang berkaitan dengan sertifikat hak milik dan buku tanah secara keseluruhan data yang telah didaftarkan kemudian diverifikasi apakah sudah sesuai aslinya atau ada beberapa berkas yang perlu diperbaiki lagi

Demi mendapatkan sertifikat hak tanggungan selain memerlukan waktu yang panjang harus dihadiri atau diwakilkan oleh pihak yang bersangkutan. Pembuatan sertifikat harus di Kantor Pertanahan, para pihak diharapkan mengikuti ketentuan sesuai dengan kesepatan pada awal terjadinya konflik antar para pihak. Setelah sertifikat rampung dilakukan irah-irah yaitu dengan kalimat yang memiliki makna berani mempertanggungjawabkan dengan mengatas namakan Tuhan

\section{Perlindungan Hukum Terhadap Kreditor yang Objek Jaminannya telah Dibebani Hak Tanggungan Dimohonkan Perubahan dari Hak Guna Bangunan Menjadi Hak Milik}

Terkadang kreditur memberikan aturan yang terlihat seperti menyusahkan debitur akibat aturannya yang sangat ketat dalam pemberian utang kepada pihak debitur. Aturan tersebut timbul akibat menghindari adanya wanprestasi yang mungkin akan dilakukan oleh debitur dikemudian hari, selain itu debitur diwajibkan untuk tetap menerapkan asas itikad baik, dalam kegiatan utang piutang ini kedua belah pihak yang berkaitan harus menerapkan itikad baik agar dapat mendapatkan hak dan kewajibannya masing-masing sesuai dengan yang ada pada kesepakatan yang dituangkan dalam perjanjian tertulis. Pada kegiatan perjanjian kredit perlu diperhatikan dan dipertimbangkan apakah debitur terlihat layak dan sanggup untuk memenuhi hak dan kewajiban yang akan dibuat karena dalam kreditur memberikan kredit tidak bisa berpatokan hanya dengan prinsip kehati-hatian. Hal tersebut sangatlah penting agar mencapai kelancaran perjanjian kredit ini terpenuhi dan bisa berjagajaga apabila debitur melakukan wanprestasi dikemudian hari, maka kreditor dapat melakanakan prosedur yang sudah sesuai perjanjian untuk mendapatkan hak dan kewajibannya kembalibeberapa prosedur dalam mengawasi dan memeriksa pada saat perjanjian kredit berjalan yaitu:

a. Selalu mengecek laporan secara rutin ataupun bertahap

b. Mengecek yang berkaitan dengan admin ataupun pembukuan yang ada

c. Mengecek kondisi usaha yang sedang dilakukan secara menyuluruh jika dalam awal peminjaman kredit segai modal untuk membuka usaha

Kreditur memiliki batasan pengetahuan dalam praktek lapangan mengenai pemilik utangnya karena kreditur mengetahui perkembangan informasinya hanya dengan keterangan yang diinformasikan oleh pemilik utang tersebut, misalnya pemilik utang saat ingin memenuhi hak dan kewajiban yang telah disepakati diperjanjian awal dan mengalami kendala untuk memenuhinya maka pihak kreditur yakni pemberi piutang terkadang tidak mengetahui apa sumber permasalahan tidak dapat dipenuhinya sesuai dengan perjanjian diawal. Apabila hal seperti ini sudah terjadi maka permasalahan ini akan diserahkan kepada oleh pihak yang berwenang untuk penyelesaiannya, karena tidak terpenuhinya hak dan kewajiban maka pemilik utang dianggap mengingkari perjanjian yang sudah dibuat, dan dia disebut melakukan wanprestasi. Bentuk dari wanprestasi pemilik utang ialah tidak membayaran cicilan utangnya ataupun bunga yang timbul dari utang tersebut secara rutin. Akibat dari hal ini maka pihak kreditur memiliki hak untuk mengamankan atas kepentingan instansinya sendiri misalkan pemilik utang tetap tidak ingin memenuhi kewajibannya terhadap pemberi utang dengan sengaja maka pemberi utang memiliki wewenang untung mengajukan tindakan guna untuk menyelamatkan instansinya ataupun untuk penyelesaian sengketa yang ada

Pada UUHT untuk terlaksananya penggantian HGB yang masih memiliki status sebagai jaminan jadi hak milik memiliki resiko hukum yakni hak tanggungan yang berkaitan dapat menjadi hilang. Karena dihilangkannya status pada tanah yang di jadikan jaminan HT tetapi utang yang sedang berjalan tetap ada. Hal ini berakibat kepada pihak pemberi utang yang memiliki hak atas tanahnya menjadi kreditur tidak mempunyai hak untuk lunas dahulu dari pada pemberi utang lainnya 
dan piutang pemberi utang tidak memiliki jaminan atas bendanya dan juga tidak mendapatkan fasilitas payung hukum, apabila ada sengketa pemberi utang tidak dapat berbuat apa-apa apabila dikemudian hari pemilik utang tidak memenuhi hak dan kewajibannya sesuai dari perjanjian awal mereka, sedangkan pemberi utang yang berstatus konkuren dapat melakukan penyelesaian sengketa diluar pengadilan ataupun mengajukan gugatan ke meja hijau, dengan dihapusnya hak terhadap tanah yang dibebaninya maka hak tanggungan yang bersangkutan akan menjadi gugur atau hilang. Hal ini memberikan pengertian bahwa pemberi utang yang memegang hak tanggungan dapat mengajukan anggunan lain atau rekening debitur untuk sementara diblokir

\section{SIMPULAN DAN SARAN}

\section{Simpulan}

Berdasarkan hasil analisis data dapat disimpulkan bahwa pelaksanaan perubahan hak guna bangunan menjadi hak milik akan diproses berdasarkan ketentuan PERMEN Agraria 5/1998 tentang Perubahan Hak Guna Bangunan atau Hak Pakai Atas Tanah untuk Rumah Tinggal yang dibebani Hak Tanggunan menjadi Hak Milik Penggantian yang akan dilakukan berdasarkan keinginan pemilik hak dengan melampirkan persetujuan yang tertulis dari pemilik HT serta sertifikat HT pada kantor yang berwenang dan tempat dimana hak tanggungan itu ada, yang kedua untuk mendapatkan hak guna bangunan ada resiko yang sudah menanti dimana seorang atau pihak selama masih memiliki Tanggungan maka dapat dikatakan memiliki akibat hukum dinyatakan gugur yaitu dihapuskannya dana yang dijamin Sesuai dengan aturan pemerintah sama poinnya yaitu tidak menghapus hutang yang akan digunakan untuk melunasi hutang negara atau menunjang kegiatan kepemerintahan

\section{Saran}

Dari hasil penelitian ini, adapun yang disarankan oleh peneliti adalah kepada pemerintah diharapkan pada pembuatan surat pernyataan pelepasan hak dicantumkan bunyi bahwa apabila kemudian ternyata permohonan hak milik tersebut ditolak oleh yang berwenang maka surat pernyataan pelepasan hak ini dianggap batal dan tanah tersebut tetap statusnya sebagai hak guna bangunan atas nama saya. Hal tersebut berguna untuk melindungi kepentingan pemohon dan tidak merugikan pemohon apabila permohonan hak miliknya tidak dikabulkan, yang kedua hak tanggungan yang baru yang sudah memiliki beban hak milik sebaiknya dibuatkan setelah sertifikat atas tanah yang sudah diubah jadi hak milik agar pihak pemberi utang atau kreditur memiliki penjamin untuk kepastian hukumnya jika debitur wanprestasi.

\section{DAFTAR PUSTAKA}

Adrian, S. (2014). Peralihan Hak atas Tanah dan Pendaftarannya. Sinar Grafika.

Asikin, Z. (1997). Aspek-Aspek Hukum Hak Pakai atas Tanah Sebagai Obyek Jaminan. Djambanan.

Hermayulis. (2000). Aspek-Aspek Hukum Hak Pakai atas Tanah Negara Sebagai Objek Jaminan. Lex Crimen, 6(4), 103-111.

JW, W. (2009). Pemberian Hak Milik untuk Rumah Tinggal Cerdas.

Prodjodikoro, W. (2011). Asas-Asas Hukum Perjanjian. Bale Bandungg.

Rahman, T. (2010). Akibat Hukum Kebijakan Deregulasi Peningkatan Hak Atas Tanah Perumahan Terhadap Perjanjian Kpr yang Memuat Klausula Pembebanan Hak Tanggungan. Law Reform, 5(2), 1-46.

Sofiatun, N. (2017). Analisis Pelaksanaan Perubahan Hak Guna Bangunan Untuk Rumah Tinggal yang Diberi Hak Tanggungan Menjadi Hak Milik. Jurnal Akta, 4(1)

Sugiyono. (2005). MemahamiPenelitian Kualitatif. Alfabeta.

Urip, S. (2013). Pendaftaran dan Peralihan Hak atas Tanah cetakan kelima PT Adhitya Andrebina Agung Jakarta. PT Adhitya Andrebina Agung.

Usman, R. (1999). Pasal-Pasal tentang Hak Tanggungan Hak Atas Tanah. Djambatan. 